\title{
Basil (Ocimum basilicum L.) and/or Celery (Apium graveolens L.) Leaves Aqueous Extracts Role in Opposition to Drinking Contaminated Water Induced Male Rats Urinary Stones and Renal Deteriorations
}

\author{
Alyae M. S. Gabal ${ }^{1^{*}}$ \\ ${ }^{1}$ Biochemistry and Nutrition Department, Faculty of Women for Arts, Science and Education, \\ Ain Shams University, Cairo, Egypt. \\ Author's contribution \\ The sole author designed, analyzed, interpreted and prepared the manuscript. \\ Article Information \\ DOI: 10.9734/ARRB/2020/v35i1130299 \\ Editor(s): \\ (1) Dr. Paola Angelini, University of Perugia, Italy \\ Reviewers: \\ (1) Mohuya Chakraborty, Institute of Engineering \& Management, India. \\ (2) Shapoval Olha, Kharkiv National Medical University, Ukraine. \\ Complete Peer review History: http://www.sdiarticle4.com/review-history/62116
}

Original Research Article

Received 10 August 2020

Accepted 15 October 2020

Published 12 November 2020

\begin{abstract}
Aims: The current research was designed to explore the role of basil and/or celery leaves aqueous extracts against urinary stones (urolithiasis) and renal deteriorations induced by drinking water contaminated with ethylene glycol (EG) and ammonium chloride (AC) in male rats.

Place and Duration of Study: The Medical Research Center of the Faculty of Pharmacy, Al-Azhar University, Cairo, Egypt. The experiment duration was 35 days, 7 days for acclimatization followed by 28 days experimentation.

Methodology: Fifty-five adult male Sprague-Dawley rats were classified randomly into 5 groups of ten animals each, except urolithiatic control group which contained 15 rats. Rats were treated as follow: Group I: healthy control group (HCG), rats drank distilled water and received a placebo $1 \mathrm{ml}$ distilled water daily by intra-gastric tube ; Group II: urolithiatic control group (UCG), rats drank distilled water containing ( $0.75 \%$ EG and $1 \%$ AC ) and the access to water was ad libitum and received $1 \mathrm{ml}$ distilled water daily by intra-gastric tube.; Group III : urolithiatic rats supplemented with aqueous basil extract $(\mathrm{U}+\mathrm{ABE})$, rats drank distilled water containing $(0.75 \% \mathrm{EG}$ and $1 \% \mathrm{AC})$ and the access to water was ad libitum and supplemented with (200mg/kg body weight) aqueous basil extract daily by intra-gastric tube.; Group IV: urolithiatic rats supplemented with aqueous celery
\end{abstract}


extract $(\mathrm{U}+\mathrm{ACE})$, rats drank distilled water containing ( $0.75 \% \mathrm{EG}$ and $1 \% \mathrm{AC}$ ) and the access to water was ad libitum and supplemented with $(200 \mathrm{mg} / \mathrm{kg}$ body weight) aqueous celery extract daily by intra-gastric tube. ; Group V: urolithiatic rats supplemented with aqueous basil and celery extract $(\mathrm{U}+\mathrm{ABE}+\mathrm{ACE})$, rats drank distilled water containing ( $0.75 \% \mathrm{EG}$ and $1 \% \mathrm{AC})$ and the access to water was ad libitum and supplemented with $(100 \mathrm{mg} / \mathrm{kg}$ body weight) aqueous basil extract and (100 $\mathrm{mg} / \mathrm{kg}$ body weight) aqueous celery extract daily by intra-gastric tube. At the end of the study 28 days, $24 \mathrm{~h}$ urine samples were collected from each individual animal and then rats were sacrificed under sodium barbiturate anesthesia. Blood samples were collected from the hepatic portal vein, serum was separated for biochemical analyses. Kidney samples were separated for tissue homogenate preparation, urinary bladder and ureters were separated and opened to collect urinary calculi.

Results: Research results documented that basil and celery aqueous extracts contain significant amount of active constituents including flavonoids and polyphenols. Drinking water contaminated with $E G$ and $A C$ caused significant decrease $(p \leq 0.01)$ in urine volume, $\mathrm{pH}$, urinary and renal magnesium levels with significant increase $(p \leq 0.01)$ in urinary and renal calcium, phosphate and oxalate levels. It also caused significant increase in kidney function tests [serum creatinine, uric acid, urea, as well as cystatin C] levels .Also renal enzyme activities of [acidic phosphatase (ACP), alanine aminotransferase (ALT), aspartate aminotransferase (AST) and alkaline phosphatase (ALP)] activities were significantly increased $(p \leq 0.01)$ with significant decrease in renal lactate dehydrogenase (LDH) activity. Water contamination also induced renal mitochondrial dysfunction (decreased complex-1 activity), apoptosis (increased caspase-3 activity) in association with a state of renal oxidative stress [increased renal malondialdehyde (MDA) level related to decreased renal reduced glutathione (GSH)level and superoxide dismutase (SOD) activity].Inflammation [increased renal tumor necrosis factor- alpha (TNF- $\alpha$ ) and interleukin 18 (IL-18)] with suppressed immune function [decreased serum immunoglobulin ( $\operatorname{lgG}$ and $\operatorname{lgM})$ ] levels were observed in urolithiatic control group. As a result of biochemical changes resulted from EG and AM administration mineral precipitation and urinary stones formation was observed in urolithiatic control group. Oral administration of aqueous basil and /or celery extracts to urolithiatic rats improved urine analysis parameters, renal functions, renal enzymes activities and mitochondrial function. Aqueous extracts also counteracted renal oxidative stress, inflammation, suppressed immune response and urinary stones formation.

Conclusion: Research results proved that aqueous basil and/or celery extracts counteracted and ameliorated urinary stones formation and renal deteriorations associated with drinking water contaminated with EG and AC due to their content of active constituents including flavonoids and polyphenols. The most significant improvements were recorded in the group supplemented with both extracts.

Keywords: Water contamination; ethylene glycol; ammonium chloride; urolithiasis; renal deteriorations; basil; celery; aqueous extracts.

\section{INTRODUCTION}

Fresh water availability affects the world economy as a reflection on human health. Water contamination became a common problem worldwide. Water contamination may be natural or man-made. The types and concentrations of natural contaminates depend on the nature of the geological materials through which the groundwater flows and quality of the recharge water [1].

Man-made water contamination is caused by secondary products of industry and agriculture, including heavy metals, hazardous chemicals, dyes and compounds like insecticides and fertilizers. Improper storing or disposing of household chemicals such as paints, detergents, oils, solvents, medicines, pesticides, batteries, gasoline and diesel fuel can lead to ground water contamination. According to United Nations report 2003 every day 2 million tons of sewage, industrial and agricultural waste are discharged into the world's water [2].

Ethylene glycol (EG) is an odorless, electrically neutral polyalcohol and a common solvent for antifreeze solutions, brake fluids, and household industrial products. The sweet taste and low cost of EG lead to its illicit use as an ethanol substitute. In cases of both accidental and purposeful ingestion, EG is rapidly absorbed 
from the gastrointestinal tract, and widely distributed throughout the body due to its miscibility with water. The first metabolic step is oxidation by alcohol and aldehyde dehydrogenases to the monoacid leading to the formation and accumulation of toxic metabolites causing metabolic acidosis. Urinary excretion as well as expiration as carbon dioxide represents the major pathway for elimination of the EG [3].

Ammonium chloride is commonly used as a buffer solution in a variety of chemical and medical applications and is also used as a fertilizer, in welding or smelting of metals, in cleansing agents, as food additives, also ammonium chloride is used as a diuretic. Ammonia may be present in drinking-water as a result of disinfection with chloramines. Also cement mortar used for the insides coating of water pipes may release considerable amounts of ammonia into drinking-water and compromise disinfection with chlorine [4].

The formation of stony concretions in body is known as lithiasis. Nephrolithiasis and urolithiasis are the main types of lithiasis that cause renal failure in human. It is the third most prevalent renal diseases affecting humans [5]. Urinary stone is a multi-factorial disorder resulted from association between epidemiological, biochemical and genetic risk factors. It occurs both in men and women but the risk is generally higher in men and is becoming more common in young women. Calcium oxalate contributes 75$90 \%$ of the total urinary stones [6].

Nutritional causes of stone formation include inadequate drinking of water or drinking contaminated water with minerals and different chemicals, systematic dehydration, obesity, high dietary intake of minerals, sugars, corn syrups, vitamin $C$ as well as vitamin $A$ and deficiency of vitamin $\mathrm{D}$. Other possible reasons include excess intake of alcohol and drugs, also may be attributed to obstruction in urine flow by microbial infections or foreign substances [7].

The medical techniques for urinary stones management includes extracorporeal shock wave, lithotripsy and percutaneous nephrolithotomy. In addition to the high cost and the issues of recurrence, there are multiple side effects associated with medical management. Side effects include renal damage and impairment, induced hypertension, sever hematuria, steinstrasse (multiple small stone blocking ureter) and pancreatitis [8].
On the other hand, there is a growing research to apply the use of herbal medicine in the treatment of urolithiasis. Herbal remedies are known to contain beneficial constituents, acting through several pathways, for example, antispasmodic, diuretic and pain relieving with no side effects associated with maximum benefits that needed for treating urolithiasis [9].

Sweet basil (Ocimum basilicum) is a herbal plant from Lamiaceae family and is known as Holy Basil in English and Rehan in Egypt. Basil leaves have been recognized as a food additive and spice but some evidence shows that these leaves can also be used to overcome different human diseases. This may be due to their phytochemical contents, including antioxidants, polyphenols and flavonoids. Essential oils as well as the most active constituents of basil are dominantly found in the leaves [10].

Celery (Apium graveolens L.) is a herbal plant, belonging to the parsley descent Umblliferace family .Celery leaves have a variety of compounds like caffeic acid, p-coumaric acid, ferulic acid, apigenin, luteolin, tannin, saponin, and kaempferol. These compounds have powerful antioxidant characteristics, and are able to chelate and fight free radicals that give celery varied healing characteristics [11].

In this study, the protective and healing effects of basil and/or celery aqueous extracts on the urinary stones and renal deteriorations induced by drinking water contaminated with ethylene glycol and ammonium chloride in male adult rats were compared and examined for the first time.

\section{MATERIALS AND METHODS}

\subsection{Materials}

\subsubsection{Chemicals}

Ethylene glycol (EG) and ammonium chloride (AC) were purchased from Sigma Aldrich Chemical Co. (St. Louis, Missouri, United States). Urolithiasis model was inducted using $0.75 \%$ EG and $1 \% \mathrm{AC}$ dissolved in drinking water (distilled water) and the access to water was ad libitum [12].

\subsubsection{Plants}

Basil and celery were purchased from The Ministry of Agriculture, Giza, Egypt .Plant leaves were verified by botanist (Department of Botany, 
Faculty of Women for Arts, Science and Education, Ain shams University).

\subsubsection{Diet}

Experimental animals were fed on standard commercial diet obtained from The Egyptian Organization for Biological Products and Vaccines (Helwan, Egypt) according to [13].

\subsubsection{Animals}

Fifty-five adult male albino rats of SpragueDawely strains weighing $(185 \pm 7 \mathrm{~g})$, were supplied by The Egyptian Organization for Biological Products and Vaccines (Helwan, Egypt).

\subsection{Methods}

\subsubsection{Preparation of plants aqueous extracts}

Basil and celery leaves were dried $\left(40-60{ }^{\circ} \mathrm{C}\right)$ and the aqueous extracts were prepared by boiling dried plant leaves with distilled water for $15 \mathrm{~min}$ in a covered container [14]. The extracts were then filtered through a clean cotton cloth. The aqueous extracts were prepared and given to tested rats at dose of $(100 \mathrm{mg}$ and $200 \mathrm{mg} / \mathrm{kg}$ body weight) $[14,15]$ via intra-gastric tube.

\subsubsection{Measurement of total polyphenols and total flavonoids contents of aqueous extracts}

The amount of total polyphenols and total flavonoids contents in each plant aqueous extract were determined by folin-ciocalteu reagent as described by $[16,17]$, respectively. The experiments were repeated in triplicate.

\subsubsection{Experimental design}

All rats were individually housed with constant controlled environments in stainless steel cages and fed on the balanced commercial diet with drinking distilled water ad libitum for 7 days to be acclimatized. Animals were classified randomly into 5 groups of ten animals each, except urolithiatic control group which contained 15 rats. Rats were treated as follow:

I. Healthy control group (HCG), rats drank distilled water and received a placebo $1 \mathrm{ml}$ distilled water daily by intra-gastric tube.

II. Urolithiatic control group(UCG), rats drank distilled water containing $(0.75 \%$ EG and $1 \%$ $\mathrm{AC}$ )and the access to water was ad libitum and received $1 \mathrm{ml}$ distilled water daily by intra-gastric tube.

III. Urolithiatic rats supplemented with aqueous basil extract $(U+A B E)$, rats drank distilled water containing $(0.75 \%$ EG and $1 \% A C)$ and the access to water was ad libitum and supplemented with $(200 \mathrm{mg} / \mathrm{kg}$ body weight) aqueous basil extract daily by intra-gastric tube.

IV. Urolithiatic rats supplemented with aqueous celery extract (U+ACE), rats drank distilled water containing $(0.75 \%$ EG and $1 \% A C)$ and the access to water was ad libitum and supplemented with (200mg/kg body weight) aqueous celery extract daily by intra-gastric tube.

V. Urolithiatic rats supplemented with aqueous basil and celery extract $(\mathrm{U}+\mathrm{ABE}+\mathrm{ACE})$, rats drank distilled water containing $(0.75 \%$ EG and $1 \% \mathrm{AC}$ ) and the access to water was ad libitum and supplemented with $(100 \mathrm{mg} / \mathrm{kg}$ body weight) aqueous basil extract and (100mg/kg body weight) aqueous celery extract daily by intra-gastric tube.

\subsubsection{Handling of urine, blood and kidney samples}

At the end of the study 28 days, individual animal was placed in the metabolic cage for collection of $24 \mathrm{~h}$ urine samples. Initially a drop of concentrated hydrochloric acid was added to the test tubes as a preservative [18]. After urine collection period, rats were sacrificed under sodium barbiturate anesthesia. Blood samples were collected from the hepatic portal vein, serum was separated for biochemical analyses. Kidney samples were separated, rinsed, dried on filter paper, homogenized in Tris hydrochloride (Tris- $\mathrm{HCl})$ buffer ( $\mathrm{pH} \mathrm{7.4)} \mathrm{and} \mathrm{centrifuged.} \mathrm{The}$ resulting supernatants were stored at $-80^{\circ} \mathrm{C}$ immediately until doing the biochemical analysis. Urinary bladder and ureters were separated and opened to collect urinary calculi.

\subsubsection{Biochemical analysis}

\subsubsection{Urine samples}

Urine samples were tested for total volume in a measuring cylinder and reported in Milliliter $(\mathrm{mL})$, $\mathrm{pH}$ of each sample was measured using $\mathrm{pH}$ meter [19].Urinary oxalate, calcium, magnesium and phosphate concentration were determined using Biodiagnostic kits, Giza, Egypt.

\subsubsection{Serum samples}

Serum uric acid, urea and creatinine levels were determined according to [20-22] using Biodiagnostic kits, Giza, Egypt. Serum cystatin C 
was determined using ELISA assay technique according to the method described by Pergande and Jung [23]. Immunoglobulins $G$ and $M$ (IgG and $\lg \mathrm{M}$ ) concentrations were measured using Biocientifica kit, San Diego, USA.

\subsubsection{Kidney samples}

Renal complex I activity, malondialdehyde (MDA),reduced glutathione (GSH)levels and superoxidedismutase (SOD) activity were determined according to [24-27].Renal oxalate, calcium, magnesium and phosphate levels as well as renal acidic phosphatase(ACP), alkaline phosphatase $(A L P)$, Alanine aminotransferase (ALT), aspartate aminotransferase (AST) activities were determined using Biodiagnostic kits, Giza, Egypt. Renal lactate dehydrogenase $(\mathrm{LDH})$ activity was determined according to standard methods using diagnostic kits from BioSystems S.A. (Barcelona, Spain), caspase-3 was determined following ELISA MyBioSource kit standard method. Tumor necrosis factor alpha (TNF- $\alpha$ ) as well as interleukin eighteen (IL-18) levels were determined using Koma Biotech and MyBioSource ELISA kits according to [28,29].

\subsubsection{Weight of calculi}

The urinary bladders and ureters were opened by incision. The adhered crystals were removed and weighed using digital balance [30].

\subsubsection{Statistical analysis}

Results were expressed as mean \pm Standard deviation (S.D) of the mean. Differences among means were tested for statistical significance by one-way analysis of variance using SPSS package version 20. Statistical significance was considered when $P \leq 0.01$ according to [31].

\section{RESULTS AND DISCUSSION}

\subsection{Aqueous Basil and Celery Extracts Total Flavonoids and Total Polyphenols Contents}

Flavonoids and phenolic compounds are the main medicinal plants active constituents. The analysis of aqueous basil extract (ABE) and aqueous celery extract (ACE) as illustrated in Fig. 1 revealed that both plants extracts contain valuable amount of flavonoids and polyphenols in comparison with their price. The aqueous basil extract contained (2.59mg flavonoids/100mg extract) and (4.86 mg polyphenols/100mg extract) while the aqueous celery extract contained (1.87 $\mathrm{mg}$ flavonoids/100mg extract) and (3.95 mg polyphenols/100mg extract).

Flavonoids possess antioxidant power by efficiently scavenging various free radicals. Flavonoids act through modulating antioxidant

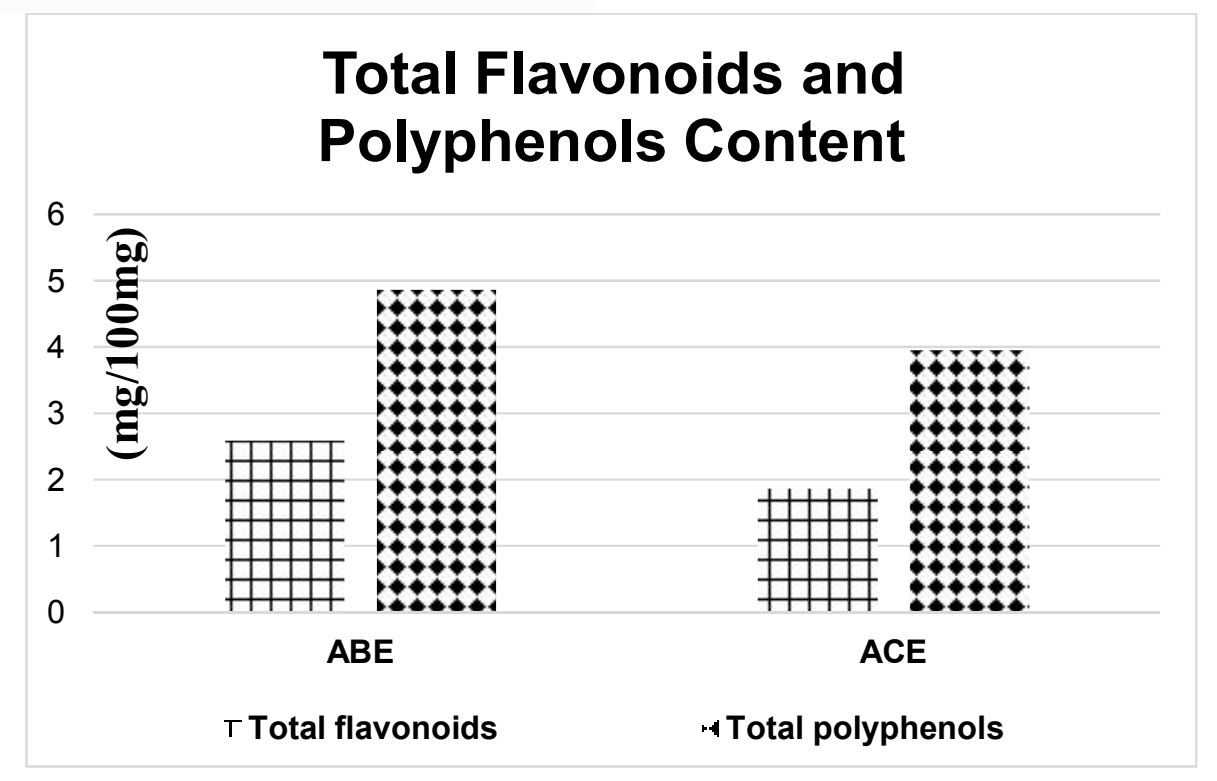

Fig. 1. Aqueous basil and celery extracts total flavonoids and total polyphenols contents 
enzymes activities as well as catching metals accompanied with processes of radical production [32]. While phenolic compounds are the main secondary metabolites in plants. Phenolics have antioxidant associated with antiinflammatory capability. Also phenolics can regulate enzyme activity and gene expression [33].

The results go hand in hand with [34, 35] who confirmed that basil and celery and their aqueous extract contain significant amount of phytochemicals including flavonoids and polyphenols.

\subsection{Effect of Aqueous Basil and/or Celery Leaves Extracts on Urine Volume, $\mathrm{PH}$, Urinary and Renal Oxalate, Calcium, Magnesium and Phosphate Levels in Urolithiatic Rats}

The results in Table 1 and Fig. 2 ( $a, b$ and $c)$ revealed that rats drank on water contaminated with ethylene glycol (EG) in association with ammonium chloride (AC) for 28 days to induce urolithiasis, urinated less and their urinary and renal oxalate, calcium, and phosphate levels increased significantly $(p \leq 0.01)$ on comparison with healthy control rats that drank pure clean distilled water on the other hand water contamination decreased urine $\mathrm{pH}$, urinary as well as renal magnesium level significantly $(p \leq 0.01)$. Supplementation with aqueous basil and /or celery extracts improved significantly $(p \leq 0.01)$ the urine volume, $\mathrm{pH}$, urinary and renal oxalate, calcium, magnesium and phosphate levels in urolithiatic rats in comparison with urolithiatic control rats.

Urinary super saturation is one of the main causative factors in calculogenesis with respect to stone-forming constituents. Fourteen days continued administration of ethylene glycol (EG) to young albino rats led the formation of renal calculi composed mainly of calcium oxalate [36]. Also it resulted in increase in urine and renal concentration of oxalate as well as phosphate stones. Administration of $0.75 \%(\mathrm{v} / \mathrm{v})$ EG solution caused formation of toxic metabolites inside the body resulting in metabolic acidosis due to the accumulation of acid metabolite and lactate. Renal calcium oxalate deposition by EG and ammonium chloride in rats is mainly used to mimic the urinary stone formation in humans. Ammonium chloride reported to accelerate the lithiaisis [37]. The stones induced obstruction of urine flow leading to decreased urine output and urine volume in urolithiatic rats.EG and $A C$ administration results in decreased urine $\mathrm{pH}$ as acidity encourages salts precipitation and crystallization.

Table 1. Effect of aqueous basil and/or celery leaves extracts on renal oxalate, calcium, magnesium and phosphate levels in urolithiatic rats

\begin{tabular}{|c|c|c|c|c|}
\hline Group $\quad$ Parameter & $\begin{array}{l}\text { Renal oxalate } \\
(\mathrm{mg} / \mathrm{g})\end{array}$ & $\begin{array}{l}\text { Renal calcium } \\
(\mathrm{mg} / \mathrm{g})\end{array}$ & $\begin{array}{l}\text { Renal magnesium } \\
(\mathrm{mg} / \mathrm{g})\end{array}$ & $\begin{array}{l}\text { Renal Phosphate } \\
\text { (mg/g) }\end{array}$ \\
\hline $\begin{array}{l}\text { Healthy control } \\
\text { Group }\end{array}$ & $1.44 \pm 0.19^{\mathrm{e}}$ & $2.48 \pm 0.09^{\mathrm{e}}$ & $6.92 \pm 2.03^{\mathrm{a}}$ & $2.07 \pm 0.18^{\mathrm{e}}$ \\
\hline $\begin{array}{l}\text { Urolithiatic control } \\
\text { Group }\end{array}$ & $6.53 \pm 1.34^{\mathrm{a}}$ & $5.77 \pm 0.79^{\mathrm{a}}$ & $2.84 \pm 0.41^{\mathrm{e}}$ & $4.78 \pm 0.83^{\mathrm{a}}$ \\
\hline $\begin{array}{l}\text { Urolithiatic rats } \\
\text { supplemented } \\
\text { with aqueous } \\
\text { basil extract }\end{array}$ & $3.84 \pm 0.62^{c}$ & $3.89 \pm 0.51^{\mathrm{c}}$ & $4.14 \pm 0.93^{\mathrm{c}}$ & $3.19 \pm 0.45^{\mathrm{c}}$ \\
\hline $\begin{array}{l}\text { Urolithiatic rats } \\
\text { supplemented } \\
\text { with aqueous } \\
\text { celery extract }\end{array}$ & $5.13 \pm 0.84^{b}$ & $4.53 \pm 0.18^{b}$ & $3.65 \pm 0.60^{d}$ & $4.02 \pm 0.53^{b}$ \\
\hline $\begin{array}{l}\text { Urolithiatic rats } \\
\text { supplemented } \\
\text { with aqueous } \\
\text { basil and celery } \\
\text { extract }\end{array}$ & $2.32 \pm 0.71^{\mathrm{d}}$ & $3.12 \pm 0.31^{\mathrm{d}}$ & $5.26 \pm 1.01^{b}$ & $2.64 \pm 0.06^{\mathrm{d}}$ \\
\hline
\end{tabular}

Values are expressed as means $\pm S . D, n=10$.

There was no significant difference between means have the same alphabetical superscripts letter in the same column. $(p \leq 0.01)$ 


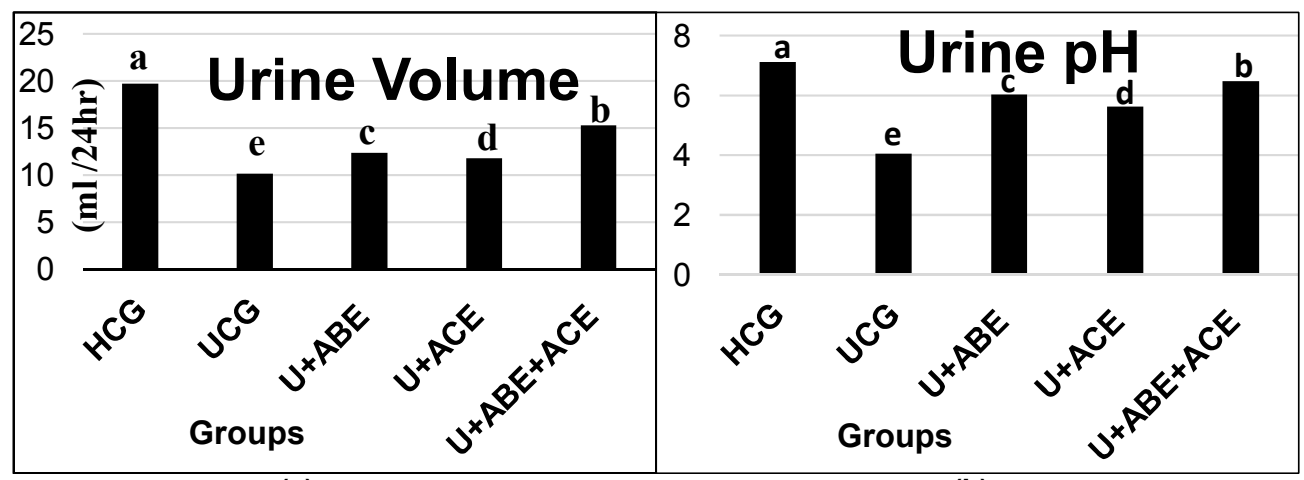

(a)

(b)

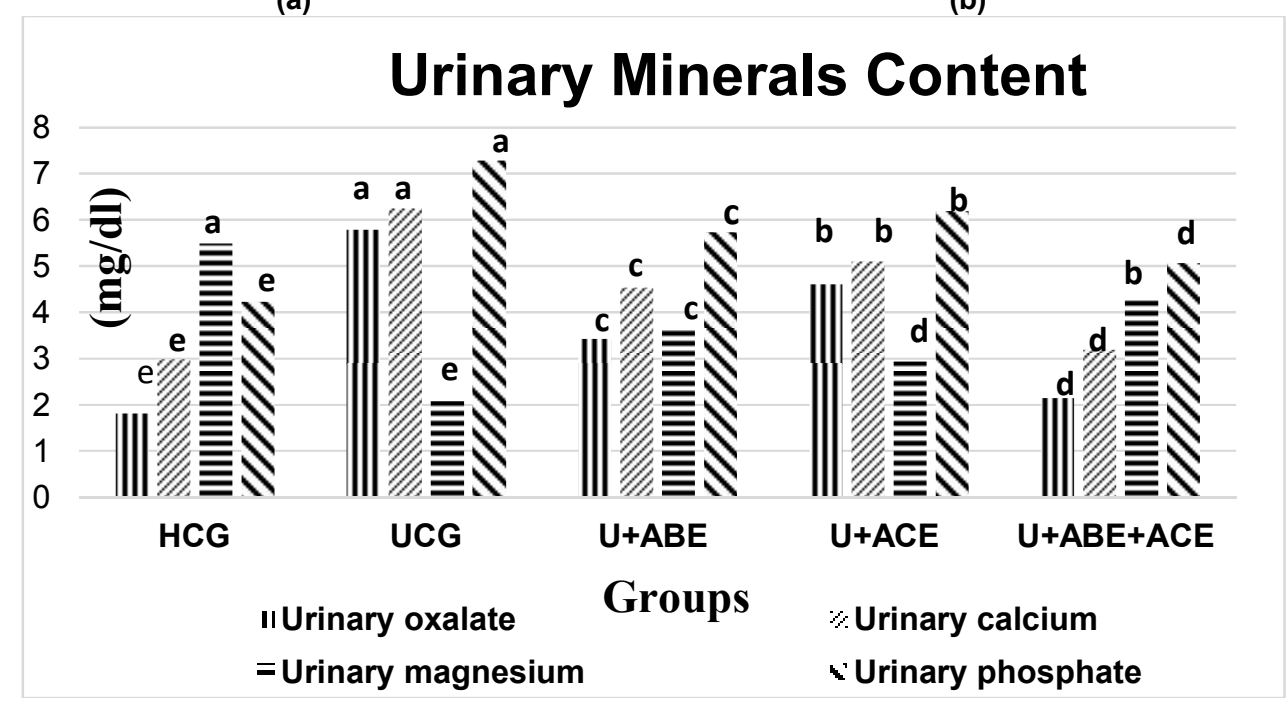

(c)

Fig. 2. Effect of aqueous basil and/or celery leaves extracts on (a) urine volume, (b) urine pH and (c) urinary oxalate, calcium, magnesium and phosphate levels in urolithiatic rats.

Values are expressed as means $\pm S$. $D, n=10$. Column of histogram with different letters are significantly different at $(p \leq 0.01)$

Also the most components of kidney stones are inorganic materials, with a small percentage of organic material; $90 \%$ of the inorganic components are calcium, oxalate and phosphate While magnesium is one of the inhibitors of crystallization, as encountered in EG and $A C$ induced urolithiasis, and it decreases the super saturation of stony formation resulting in reduced crystal growth [6, 30, 38].

Aqueous basil and celery extracts significantly improved the urine volume that decreased the crystal formation rate as well as facilitated the flushing out of crystals and raised urine $\mathrm{pH}$ that prevented the stone formation by preventing salt precipitation. Supplementation also decreased urinary and renal calcium, oxalate and phosphate levels while increased magnesium levels that decreased stony formation. The best effects were seen in the group that supplemented with both basil and celery aqueous extracts.

\subsection{Impact of Aqueous Basil and/or Celery Leaves Extracts on Serum Creatinine, Uric Acid, Urea and Cyc-C Levels in Urolithiatic Rats}

As a result of increased mineral precipitation leading to formation of urinary and kidney crystals and stones that causes obstruction of urinary tract and retention in renal tubules leading to renal tissues damage, decreasing the glomerular filtration rate and facilitating accumulation of different waste products especially nitrogenous substances in blood [3840]. Fig. 3 ( $a$ and $b$ ) illustrated that administration of $E G$ and $A C$ resulted in increased serum level and accumulation of nitrogenous waste products 
like creatinine, uric acid and urea, associated with increased serum cystatin $C$ (Cyc-C) level significantly $(p \leq 0.01)$. Cys- $C$ is a preliminary marker of renal deterioration compared to familiar markers as creatinine and can reveal mild to moderate kidney problems .Cyc-C is a produced non-glycosylated protein present in all nucleated cells and is refined by glomeruli and then metabolized in proximal renal tubule cells. Cys-C is the fundamental protector of the glomerular membrane from destruction by cysteine proteinases. The impaired renal tissue is indicated by decreased glomerular filtration rate and identified by the raised serum cystatin $\mathrm{C}$ [41].

Basil and celery extract supplementation to urolithiatic rats, counteracted kidney tissues deteriorations and improved kidney function as well as glomerular filtration rate significantly $(p \leq 0.01)$ in all treated groups especially the group that supplemented with both extracts as basil and celery active constituents prevented salts precipitation and increased urine flow that maintained normal kidney functions.

\subsection{Effect of Aqueous Basil and/or Celery Leaves Extracts on Renal ACP, ALP, ALT, AST and LDH Activities in Urolithiatic Rats}

The present research results Table 2. revealed that $E G$ and $A C$ administration to rats induced a significant $(p \leq 0.01)$ renal deterioration associated with kidney tissues degeneration resulting in increased enzymes activities of ACP, ALP, ALT and AST in renal homogenates of urolithiatic control group accompanied by decreased LDH activity when compared to healthy control group.

Table 2. Effect of aqueous basil and/or celery leaves extracts on renal ACP, ALP, ALT, AST and LDH activities in urolithiatic rats

\begin{tabular}{llllll}
\hline \multicolumn{1}{c}{ Parameter } & ACP (U/L) & ALP (U/L) & ALT (U/L) & AST (U/L) & LDH (U/L) \\
Group & $0.64 \pm 0.04^{\mathrm{e}}$ & $10.48 \pm 1.33^{\mathrm{e}}$ & $32.10 \pm 1.67^{\mathrm{e}}$ & $59.19 \pm 3.01^{\mathrm{e}}$ & $6.02 \pm 0.38^{\mathrm{a}}$ \\
\hline Healthy control group & $2.38 \pm 0.41^{\mathrm{a}}$ & $27.84 \pm 3.56^{\mathrm{a}}$ & $66.93 \pm 5.83^{\mathrm{a}}$ & $87.42 \pm 6.829^{\mathrm{a}}$ & $2.30 \pm 0.16^{\mathrm{e}}$ \\
\hline Urolithiatic control group & $1.37 \pm 0.16^{\mathrm{c}}$ & $20.50 \pm 1.05^{\mathrm{c}}$ & $48.96 \pm 2.30^{\mathrm{c}}$ & $69.37 \pm 2.15^{\mathrm{c}}$ & $4.23 \pm 0.18^{\mathrm{c}}$ \\
\hline $\begin{array}{l}\text { Urolithiatic rats } \\
\text { supplemented with aqueous } \\
\text { basil extract }\end{array}$ & & & & & \\
$\begin{array}{l}\text { Urolithiatic rats supplemented } \\
\text { with aqueous celery extract }\end{array}$ & $1.82 \pm 0.32^{\mathrm{b}}$ & $23.37 \pm 1.21^{\mathrm{b}}$ & $54.07 \pm 1.24^{\mathrm{b}}$ & $73.25 \pm 4.08^{\mathrm{b}}$ & $3.10 \pm 0.20^{\mathrm{d}}$ \\
$\begin{array}{l}\text { Urolithiatic rats supplemented } \\
\text { with aqueous basil and celery } \\
\text { extract }\end{array}$ & $0.91 \pm 0.08^{\mathrm{d}}$ & $18.42 \pm 0.95^{\mathrm{d}}$ & $43.38 \pm 1.08^{\mathrm{d}}$ & $60.04 \pm 2.05^{\mathrm{d}}$ & $5.81 \pm 0.69^{\mathrm{b}}$ \\
\hline
\end{tabular}

Values are expressed as means $\pm S . D, n=10$.

There was no significant difference between means have the same alphabetical superscripts letter in the same column. $(p \leq 0.01)$

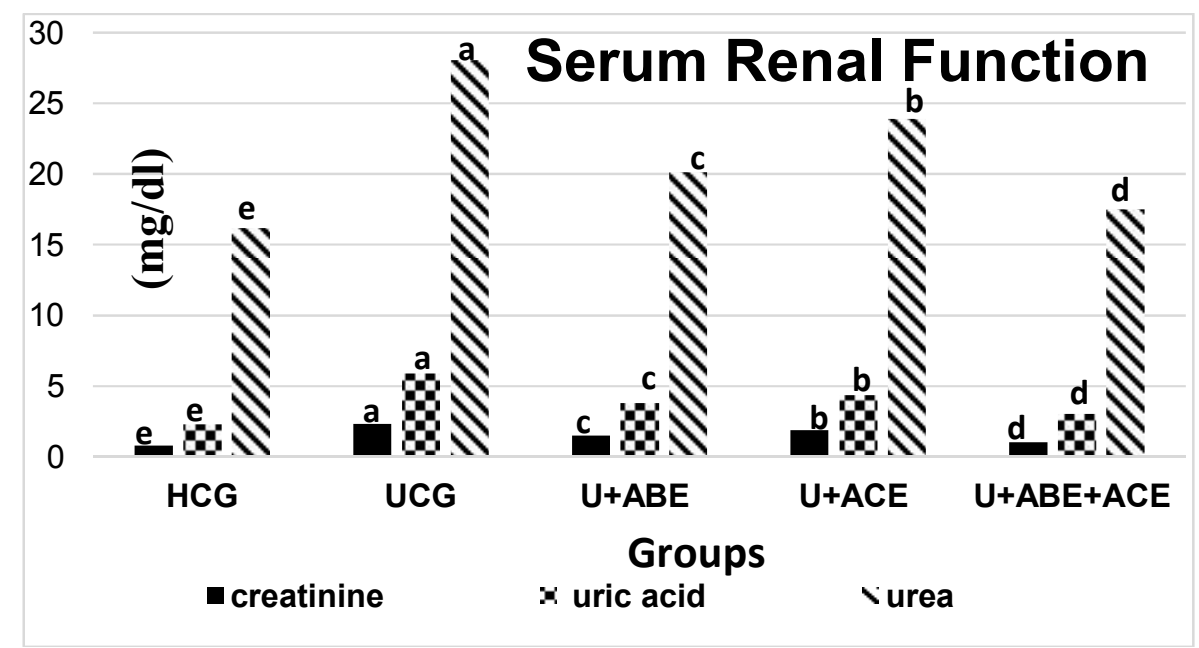

(a) 


\section{Serum Cyc-C Level}

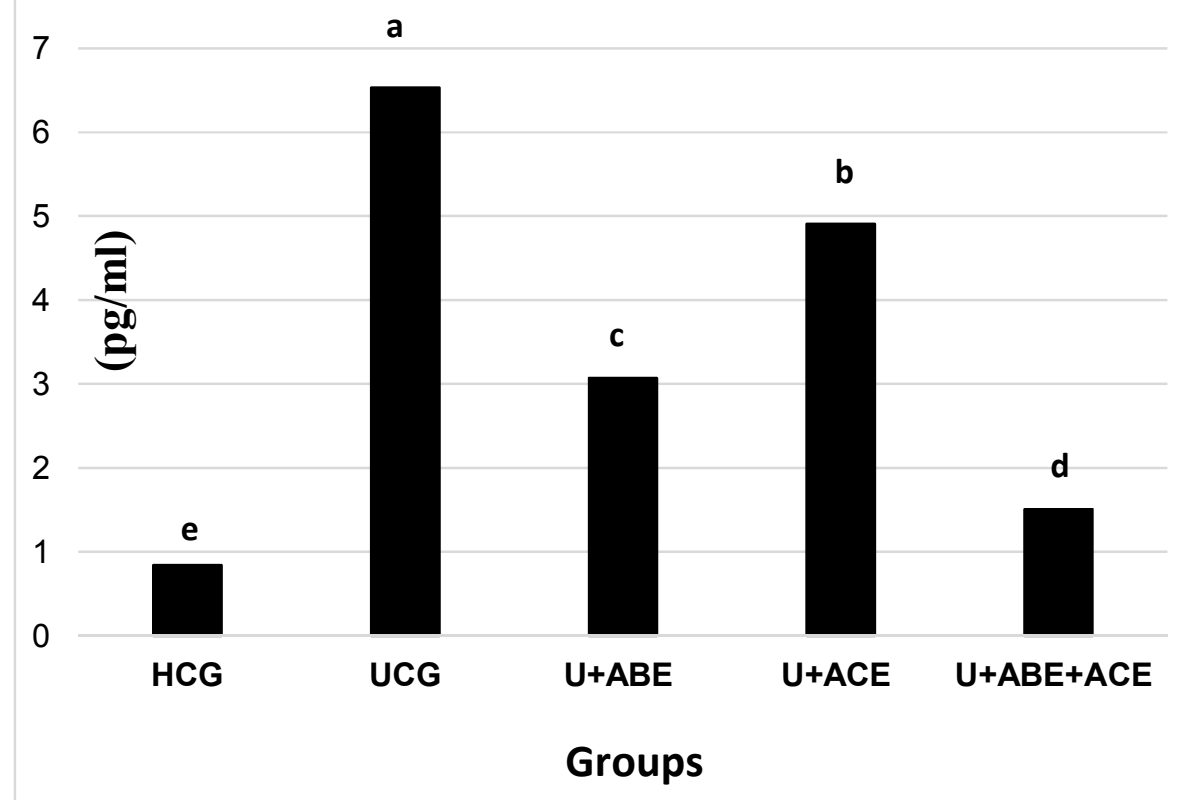

(b)

Fig. 3. Impact of aqueous basil and/or celery leaves extracts on (a) serum renal function (creatinine, uric acid and urea) levels and (b) serum cyc-c level in urolithiatic rats Values are expressed as means $\pm S$. $D, n=10$. Column of histogram with different letters are significantly different at $(p \leq 0.01)$

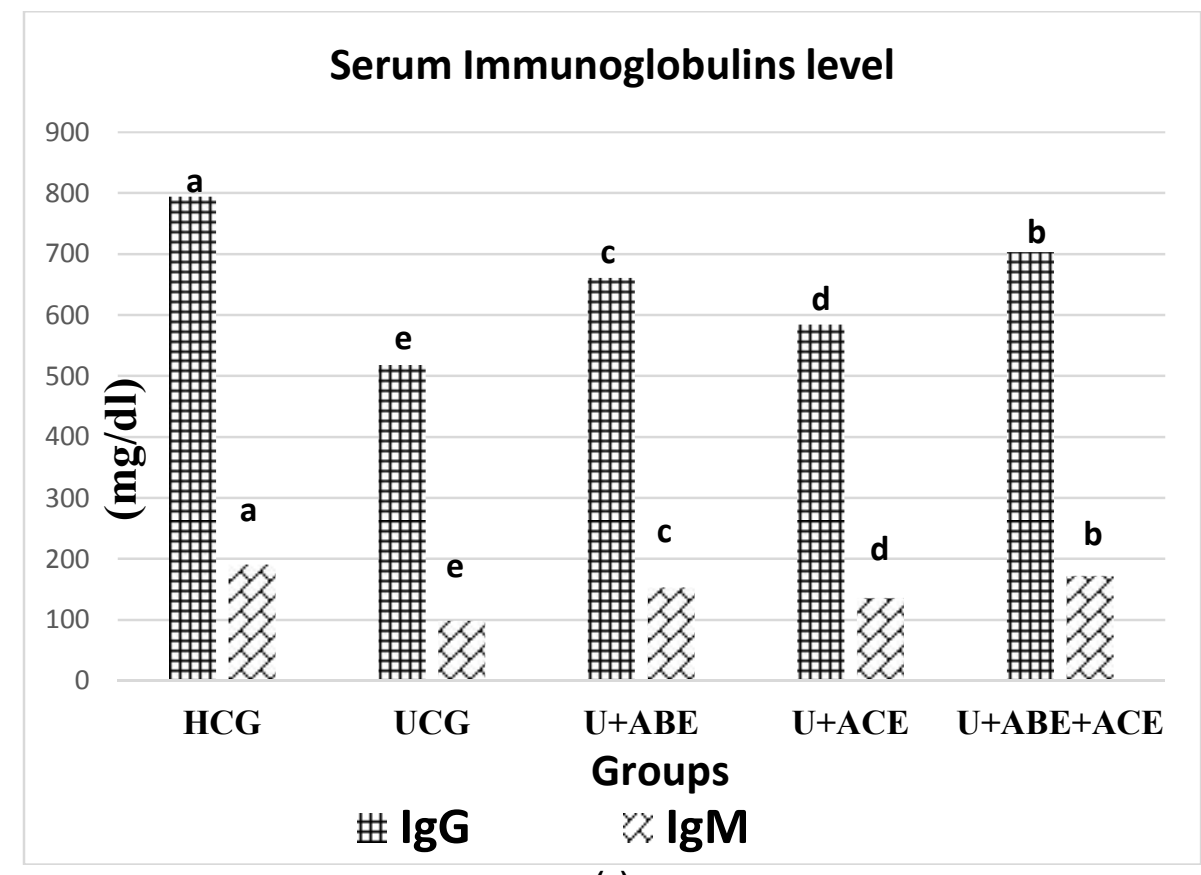

(a) 


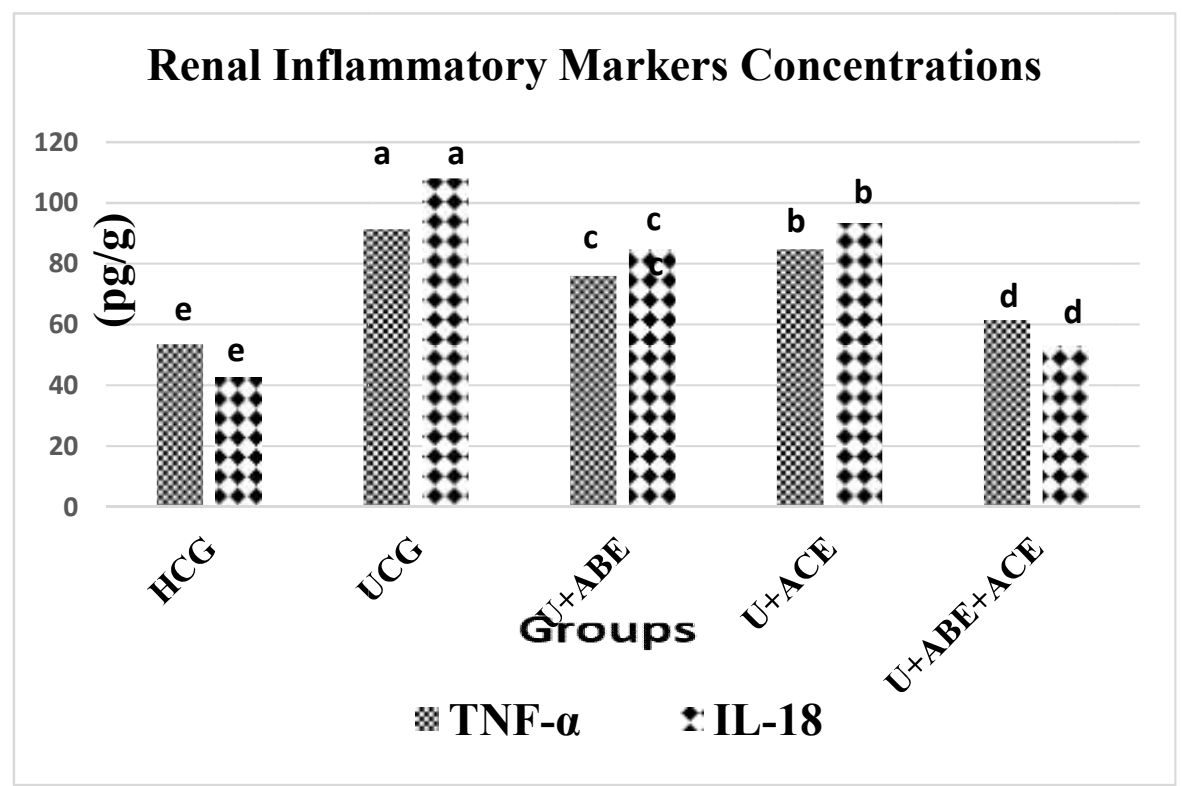

(b)

Fig. 4. Effect of aqueous basil and/or celery leaves extracts on (a) serum IgG, IgM levels and (b) renal TNF- $\alpha$ and IL-1 $\beta$ levels in urolithiatic rats.

Values are expressed as means $\pm S$. $D, n=10$. Column of histogram with different letters are significantly different at $(p \leq 0.01)$

The alterations in these injury marker enzymes in urolithiatic control group suggested damage to the brush border membrane of the renal tubules associated with progressive damage in the membrane integrity, which appears to associate with the retention and deposition of crystals in the kidney [40,42, 43]. On the other hand administration of basil and /or celery extracts normalized these enzymes activities by preventing crystals deposition and maintaining kidney integrity and functions.

\subsection{Impact of Aqueous Basil and/or Celery Leaves Extracts on Renal Mitochondrial Function, Apoptosis and Oxidative Status in Urolithiatic Rats}

Mitochondrial function is essential to regulate energy production and redox signaling in healthy well acting cells. Kidney stone disease were found to impair renal mitochondrial functions as indicated by decreased complex 1 activity in urolithiatic control group significantly $(p \leq 0.01)$.Complex 1 (NADH: ubiquinone oxidoreductase) has many important functions including; help in movement of protons across the inner mitochondrial membrane that promote ATP production for mitochondrial and cell function as well as movement of solute across the membrane $[40,44]$.

Increased caspase-3 activity (an important mediator of programmed cell death), progressing to apoptosis was recorded in urolithiatic rats and were stated previously leading to the mitochondrial apoptotic pathway activation in the kidney tissue during forming stone [45,46]. On the contrary, supplementation with plants extracts reversed back the caspase-3 activity indicating the potential inhibitory role of basil and /or celery against programmed cell death.

Free radicals generation and oxidative stress was induced as indicated in Table 3 by increased renal MDA level associated with decreased GSH level and SOD activity. Oxidative stress influenced complex 1 activity and it is probably the most susceptible component of the electron transport chain. Patients with kidney stones were found to have less activity of antioxidant enzymes with increased lipid peroxidation [4749].Increased activities of complex 1 and SOD as well as GSH level associated with decreased MDA level and caspase-3 activity in the kidney of animals administered basil and /or celery aqueous extracts could be attributed to the polyphenols and flavonoids contents that give an antioxidant potential of the extracts as seen in the current study. 
Table 3. Impact of aqueous basil and/or celery leaves extracts on renal mitochondrial function, apoptosis and oxidative status in urolithiatic rats

\begin{tabular}{|c|c|c|c|c|c|}
\hline Group Parameter & $\begin{array}{l}\text { Complex } 1 \\
\text { ( } \mu \mathrm{mol} \text { NADH } \\
\text { oxidized } / \mathrm{min} / \mathrm{mg} \text { ) }\end{array}$ & $\begin{array}{l}\text { Caspase-3 } \\
\text { (ng/mg) }\end{array}$ & $\begin{array}{l}\text { MDA } \\
(\mu \mathrm{mol} / \mathrm{g})\end{array}$ & SOD (U/g) & GSH (mg/g) \\
\hline Healthy control group & $1.04 \pm 0.12^{\mathrm{a}}$ & $3.17 \pm 0.21^{\mathrm{e}}$ & $0.58 \pm 0.03^{\mathrm{e}}$ & $6.08 \pm 1.82^{\mathrm{a}}$ & $9.85 \pm 2.04^{\mathrm{a}}$ \\
\hline $\begin{array}{l}\text { Urolithiatic control } \\
\text { group }\end{array}$ & $0.37 \pm 0.03^{e}$ & $10.95 \pm 1.84^{\mathrm{a}}$ & $4.69 \pm 0.73^{a}$ & $2.70 \pm 0.23^{\mathrm{e}}$ & $5.04 \pm 1.14^{\mathrm{e}}$ \\
\hline $\begin{array}{l}\text { Urolithiatic rats } \\
\text { supplemented with } \\
\text { aqueous basil extract }\end{array}$ & $0.63 \pm 0.04^{\mathrm{C}}$ & $7.36 \pm 0.87^{c}$ & $1.94 \pm 0.18^{\mathrm{C}}$ & $4.63 \pm 0.75^{\mathrm{C}}$ & $6.93 \pm 0.82^{C}$ \\
\hline $\begin{array}{l}\text { Urolithiatic rats } \\
\text { supplemented with } \\
\text { aqueous celery extract }\end{array}$ & $0.49 \pm 0.05^{\mathrm{d}}$ & $9.08 \pm 1.23^{b}$ & $3.21 \pm 0.28^{b}$ & $3.29 \pm 0.59^{\mathrm{d}}$ & $6.07 \pm 0.36^{\mathrm{d}}$ \\
\hline $\begin{array}{l}\text { Urolithiatic rats } \\
\text { supplemented with } \\
\text { aqueous basil and } \\
\text { celery extract }\end{array}$ & $0.81 \pm 0.07^{b}$ & $4.70 \pm 0.52^{\mathrm{d}}$ & $1.17 \pm 0.09^{d}$ & $5.72 \pm 1.19^{b}$ & $7.89 \pm 1.53^{b}$ \\
\hline
\end{tabular}

Values are expressed as means $\pm S . D, n=10$.

There was no significant difference between means have the same alphabetical superscripts letter in the same column. $(p \leq 0.01)$

Table 4. Impact of aqueous basil and/or celery leaves extracts on renal calculi weight

\begin{tabular}{|c|c|}
\hline Parameter & Calculi weight (g) \\
\hline \multicolumn{2}{|l|}{ Group } \\
\hline Healthy control group & - \\
\hline Urolithiatic control group & $1.12 \pm 0.23$ \\
\hline Urolithiatic rats supplemented with aqueous basil extract & $0.56 \pm 0.12$ \\
\hline Urolithiatic rats supplemented with aqueous celery extract & $0.84 \pm 0.09$ \\
\hline Urolithiatic rats supplemented with aqueous basil and celery extract & $0.23 \pm 0.02$ \\
\hline
\end{tabular}
Values are expressed as means $\pm S . D, n=10$

\subsection{Effect of Aqueous Basil and/or Celery Leaves Extracts on Serum IgG, IgM, Renal TNF- $\alpha$ and IL-18 Levels in Urolithiatic Rats}

The results illustrated in Fig. 4 ( $a$ and b) magnified that $E G$ and $A C$ water contamination inducing urolithiatic rat model caused suppression of immune system ability to fight infection by decreased serum levels of immunoglobulins $G$ and $M$ significantly $(p \leq 0.01)$ in urolithiatic control rats in comparison with healthy control rats and that was associated with significant renal inflammation impressed in high concentration of TNF- $\alpha$ and IL-18 in renal tissues of urolithiatic control rats. Urolithiasis caused a state of oxidative stress that suppress B cells functions leading to suppressed immune function associated with decreased IgG and IgM levels. Oxidative stress also initiate inflammatory cascades leading to increased inflammatory markers expression especially at kidney tissues [49]. Pro-inflammatory cytokines are released at the onset of the inflammation and they initiate the release of other cytokines and activate inflammatory cells. They are essential to the initiation and sustenance of immune response. Main pro-inflammatory cytokine in human immune response is TNF- $\alpha$. IL-18 as an early diagnostic biomarker of acute renal damage and increased expression of IL-18 was associated with renal damage $[50,51]$. Aqueous basil and/or celery extracts active constituents fight oxidants, ameliorated oxidative stress and were found to be able to suppress inflammatory cascades and strengthen immune system and its ability to fight microbes in urolithiatic rats.

\subsection{Impact of Aqueous Basil and/or Celery Leaves Extracts on Urinary Calculi Weight}

Rats that were drunk water contaminated with EG and AC caused precipitation of minerals in the urinary bladder and ureters forming urinary calculi. Results tabulated in Table 4 showed that formation of urinary calculi in urolithiatic control group and supplementation with aqueous basil 
and /or celery extracts prevented and decreased mineral precipitation and formation of the calculi and urolithiatic rats that supplemented with both aqueous extracts had the least calculi formation and weight due to the synergetic effect between basil and celery active constituents.

\section{CONCLUSION}

From this research results, it can be concluded that both aqueous basil and celery extracts have high content of flavonoids and polyphenols that compete with and prevent serious and dangerous effects resulted from drinking water contaminated with EG and AC for 28 days. Aqueous extracts maintained and improved renal health. The most significant improvements were recorded in the group that supplemented with both extracts. It is advised to drink basil and celery tea and adding their leaves to soups, food recipes and salads due to their health benefits, low cost and ease of availability all the year.

\section{ETHICAL APPROVAL}

This research was done following "Principles of laboratory animal care" (NIH publication No. 8523, revised 1985), as well as specific national laws. All experiments have been examined and approved by the appropriate ethics committee. All animal experimentations were carried out in conformity with the Committee for the Purpose of Control and Supervision of Experiments on Animals guidelines and were approved by the Institutional Animal Ethics Committee.

\section{COMPETING INTERESTS}

Author has declared that no competing interests exist.

\section{REFERENCES}

1. Sharma S. and Bhattacharya A. Drinking water contamination and treatment techniques Applied Water Science.2017; 7(1): 1043-1067.

2. Kumar A. and Xagoraraki I. Pharmaceuticals, personal care products and endocrine-disrupting chemicals in U.S. surface and finished drinking waters: a proposed ranking system. Science of the Total Environment.2010; 408 (23):59725989.

3. Loriaux D, Bergin SP and Patel S M. Ethylene glycol toxicity in the setting of recurrent ingestion: A Case Report and
Literature Review. Cureus. 2019;11(4): 4375.

4. Kharicha SM, Kharicha A, Mogeritsch J, Wu $M$ and Ludwig A .Review of ammonium chloride-water solution properties Journal of. Chemical and Engineering Data .2018; 63(9): 3170-3183.

5. Lonkala S. In-vitro anti-urolithiatic evaluation of tamsulosin against urolithiasis induced in wistar albino rats. Journal of Forensic Science and Toxicology. 2020; 3(1): 1011.

6. Kifayatullah M., Rahim $\mathrm{H}$, Jan $\mathrm{N} U$, Abbas A, Khan MS and Ikram M .Anti-urolithiatic effect of Pericampylus glaucus against ethylene glycol induced urolithiasis in male sprague dawley rats. Sains Malaysiana.2019; 48(5): 1075-1081.

7. Goyal PK, Verma SK and Sharma AK. Evaluation of antiurolithiatic effects of Parmelia perlata against calcium oxalate calculi in hyperoxaluric rats. Journal of Applied Pharmaceutical Science .2018; 8 (01): 129-135.

8. Li X, Wang W, Su Y, Yue Z, Bao J. Inhibitory effect of an aqueous extract of Radix Paeoniae Alba on calcium oxalate nephrolithiasis in a rat model. Renal Failure. 2017; 39(1) 120-129.

9. Ushakiran $\mathrm{CH}$, Murthy PPA, Lakshmi P $\mathrm{S}$, Mounika V, Mani J, Yothi $\mathrm{N}$ and Anitha $P$.Evaluation and antiurolithiatic activity of rapanus sativus extract by in-vivo on experimentally induced urolithiasis in rats. International journal of pharmacy and pharmaceutical analysis .2017; 1(2):71- 78

10. Rachmawati NA, Wasita B and Kartikasari LR. Basil leaves (Ocimum sanctum linn.) extract decreases total cholesterol levels in hypercholesterolemia sprague dawley rats model .IOP Conf. Series: Materials Science and Engineering.2019; 546 (6): 1-6.

11. Kooti $W$ and Daraei NA Review of the Antioxidant Activity of Celery (Apium graveolens L).Journal of Evidence-Based Complementary \& Alternative Medicine. 2017; 22(4): 1029-1034.

12. Fan J, Glass MA and Chandhoke PS. Impact of ammonium chloride administration on a rat ethylene glycol urolithiasis model .Scanning Microscopy.1999; 13(2-3): 299-306.

13. (NRC), National Research Council. Nutrient requirements of laboratory animals $4^{\text {th }}$ ed. 1995. National Academy Press, Washington, DC. 
14. Farag MFS. Utilization of basil extract as a radioprotector in male rats .Arab Journal of Nuclear Science and Applications.2013; 46(1): 274-281.

15. Hardani A, Afzalzadeh MR, Amirzargar A, Mansouri E, Meamar Z. Effects of aqueous extract of celery (Apium graveolens L.) leaves on spermatogenesis in healthy male rats. Avicenna Journal Phytomedicine. 2015; 5 (2): 111

16. Arnous A, Makrisand DP and Kefalas P. Effect of principal polyphenol components in relation to antioxidant characteristics of aged red wines. Journal of Agriculture and Food Chemistry.2001; 49: 5736.

17. Joyeux $M$, Lobestein $A$, Anton $R$, and Morier F. Comparative anti- lipoperoxidant, anti-necrotic and scavenging potencies of terpenes and bio-flavones from gingko and some flavonoids. Planta Medicine.1995; 61: 126-129.

18. Mariappan A, Ganapathy $G$ and Banumathi V. Anti-urolithiatic evaluation of siddha formulation seenakara parpam against zinc disc implantation induced urolithiasis in wistar albino rats. International Journal of Advanced Research in Biological Science. 2016; 3(12):7-13.

19. Bhave AL, Bhatt JD, Hemavathi KG. Antiulcer effect of amlodipine and its interaction with $\mathrm{H}_{2}$ blocker and proton pump inhibitor in pylorus ligated rats. Indian Journal of Pharmacology. 2006; 38(6):403407.

20. Fossati P, Prencipe L, Berti G. Use of 3, 5dichloro-2-hydroxybenzenesulfonicacid/4aminophenazone chromogenic system in direct enzymic assay of uric acid in serum and urine. Clinical Chemistry. 1980; 26: 227-231.

21. Kaplan A. Urea, Kaplan A, et al. Clinical Chemistry the C.V. Mosby Co St Louis. Toronto. Princeton. 1984; 33:1257-1260.

22. Murray RL. Creatinine, Kaplan A, et al. Clinical Chemistry the C.V. Mosby Co, St Louis, Toronto, Princeton. 1984; 32:12611266.

23. Pergande $M$, Jung $K$. Sandwich enzyme immunoassay of cystatin $C$ in serum with commercially available antibodies. Clinical Chemistry. 1993; 39(9):1885- 1890.

24. Draper $\mathrm{HH}$ and Hadley $\mathrm{M}$. Malondialdehyde determination as index of lipid peroxidation. Methods in Enzymology.1990; 186:421-431.
25. Beutler E, Duroun O, Kelly BM. Improved method for the determination of blood glutathione. Journal of Laboratory and Clinical Medicine. 1963; 61: 882-888.

26. Nishikimi M, Roa NA and Yogi $K$. The occurrence of superoxide anion in the reaction of reduced phenazine methosulphate and molecular oxygen. Journal of Biochemical and Biophysical. Research. Communications. 1972; 46:849853.

27. Birch-Machin MA and Turnbull DM .Assaying mitochondrial respiratory complex activity in mitochondria isolated from human cells and tissues. Methods Cell Biology.2001; 65:97-117.

28. Dowlati $Y$, Herrmann N, Swardfager W, Liu $H$, Sham L, Reim EK and Lanctôt KL. A meta- analysis of cytokines in major depression. Biological Psychiatry. 2010; 67:446-457.

29. Zhong F, Xu J, Yang X, Zhang Q, Gao Z, Deng Y, Zhang L and Yu C. miR-145 eliminates lipopolysaccharides-induced inflammatory injury in human fibroblast-like synoviocyte MH7A cells. Journal of Cell Biochemistry .2018;119:10059-10066.

30. Lonkala S. In-Vitro Anti-urolithiatic evaluation of tamsulosin against Uurolithiasis induced in wistar albino rats. Journal Forensic Science Toxicology. 2020; 3(1): 1011.

31. Levesque R. SPSS programming and data management: A guide for SPSS and SAS users. $4^{\text {th }}$ ed. SPSS Inc, Chicago, IL; 2007.

32. Sebastian MRA and George AM. Evaluation of tocolytic activity of aqueous seed extract of Syzygium Cumini on oxytocin induced preterm labor. Asian Journal of Pharmaceutical and Clinlical Research.2020; 13(5): 162-170.

33. Mojzer EB, Hrnॅcǐc MK, Škerge M, Knez Z, Bren U. Polyphenols: extraction methods, antioxidative action, bioavailability and anticarcinogenic effects. Molecules. 2016;21(901):1- 38.

34. Taie HAA, Salama ZA, Radwan S. Potential activity of basil plant as a source of antioxidants and anticancer agents as affected by organic and bio-organic fertilization Notulae Botanicae Horti Agrobotanici Cluj-Napoca, 38(1), 119-127.

35. Siska S, Abdul Mun'im, Bahtiar A and Suyatna F D. Effect of Apium graveolens Extract Administration on the Pharmacokinetics of Captopril in the 
Plasma of Rats .Scientia Pharmaceutia. 2018; 6:86.

36. Tzou, DT, Taguchi K, Chi T and Stoller ML. Animal models of urinary stone disease. International Journal of Surgery.2016; 36: 596-606.

37. Atmani $F$, Slimani $Y$, Mimouni M and Hacht B. Prophylaxis of calcium oxalate stones by Herniaria hirsute on experimentally induced nephrolithiasis in rats. British Journal of Urology. 2003 ;92 : 137-140.

38. Goyal PK, Verma SK and Sharma AK .Evaluation of antiurolithiatic effects of Parmelia perlata against calcium oxalate calculi in hyperoxaluric rats .Journal of Applied Pharmaceutical Science.2018; 8 (01): 129-135.

39. Salama AA,El-Kassaby MI and Hassan A. Anti-urolithiatic activity of Solanum nigrum hydroalcoholic extract in ethylene glycolinduced urolithiasis in rats .Egyptian Pharmaceutical Journal. 2019; 18:311-319.

40. Olayeriju OS,Crown OO, Elekofehinti OO, Akinmoladun AC, Olaleye MT and Akindahunsi AA. Effect of moonseed vine (Triclisia gilletii Staner) on ethane-1,2-diolinduced urolithiasis and its renotoxicity in Wistar albino rats. African Journal of Urology. $2020 ; 26: 4$.

41. Tousson E, Keshta ATH, Hussein Y, Fekry RM, Abo-Ghaneima WK. Renal protective effect of Ginkgo biloba and I-carnitine extracts against pentylenetetrazol induced toxicity, oxidative stress, injury and proliferation alternation in epileptic rats. Annual Research \& Review in Biology. 2019; 32(2):1-13.

42. Baheti DG and Kadam SS. Antiurolithiatic activity of a polyherbal formulation against calcium oxalate induced urolithiasis in rats Journal of Advanced Pharmacy Education \& Research .2013;3 (1):31-41.

43. Sudhahar $V$, Veena $C K$, Varalakshmi $P$. Antiurolithic efect of lupeol and lupeol linoleate in experimental hyperoxaluria. Journal of Natural Products .2008; 71(9):1509-1512.

44. Taylor ER, Hurrell F, Shannon RJ, Lin TK, Hirst J, Murphy MP. Reversible glutathionylation of complex I increases mitochondrial superoxide formation. Journal of Biological Chemistry .2003;278(22):19603-19610

45. Zhai W, Zheng J, Yao X, Peng B, Liu M, Huang J, Wang G, Xu Y. Catechin prevents the calcium oxalate monohydrate induced renal calcium crystallization in NRK-52E cells and the ethylene glycol induced renal stone formation in rat. BMC Complementary and Alternative Medicine. 2013; 13: 228.

46. Keleş R, Şen A, Ertaş B, Kayalı D, Eker P, Şener TE, Doğan A, Çetinel Ş, Şener G. The effects of Urtica dioica $\mathrm{L}$. ethanolic extract against urinary calculi in rats. Journal of Research in Pharmacy. 2020; 24(2): 205-217.

47. Divakar K, Pawar AT, Chandrasekhar SB, Dighe SB, Divakar G. Protective effect of the hydro-alcoholic extract of Rubia cordifolia roots against ethylene glycol induced urolithiasis in rats. Food and Chemistry Toxicology .2010; 48(4):10131018

48. Patel PK, Patel MA, Saralai MG, Gandhi TR. Antiurolithiatic effects of solanum xanthocarpum fruit extract on ethyleneglycol-induced nephrolithiasis in Rats. Journal of Young Pharmacists. 2012; 4(3): 164-170.

49. Aslan Z and Aksoy L. Anti-inflammatory effects of royal jelly on ethylene glycol induced renal inflammation in International Brazilian Journal of urology. 2015; 41: 1008-1013

50. Parikh CR, Mishra J, Thiessen-Philbrook H, Dursun $B, M a$ Q and Kelly C. Urinary IL-18 is an early predictive biomarker of acute kidney injury after cardiac surgery. Kidney International.2006; 70:199-203.

51. Faubel S, Lewis EC, Reznikov L, Ljubanovic D, Hoke TS and Somerset $H$. Cisplatin-induced acute renal failure is associated with an increase in the cytokines interleukin (IL) 1beta, IL-18, IL-6, and neutrophil infiltration in the kidney. Journal of Pharmacology Experimental Therapeutics.2007; 322:8-15.

(c) 2020 Gabal; This is an Open Access article distributed under the terms of the Creative Commons Attribution License (http://creativecommons.org/licenses/by/4.0), which permits unrestricted use, distribution, and reproduction in any medium, provided the original work is properly cited.

Peer-review history:

The peer review history for this paper can be accessed here: http://www.sdiarticle4.com/review-history/62116 